\title{
THE EFFECT OF TWIN ROW PLANTING PATTERN AND PLANT POPULATION ON YIELD AND YIELD COMPONENTS OF PEANUT (Arachis hypogaea L.) AT MAIN CROP PLANTING IN CUKUROVA REGION OF TURKEY
}

\author{
Cemal KURT ${ }^{l}$, Halil BAKAL ${ }^{1}$, Leyla GULLUOGLU ${ }^{1}$, Halis ARIOGLU ${ }^{I^{*}}$ \\ ${ }^{1}$ Cukurova University, Faculty of Agriculture, Department of Field Crops, Adana, TURKEY \\ *Corresponding author: halis@cu.edu.tr
}

Received: 08.12.2016

\begin{abstract}
This study was conducted at the Cukurova University research farm as a main crop in 2013 and 2014 in Adana, Turkey. The objective of this study was to determine the effect of twin row planting pattern and plant densities on yield and yield components of peanut. The experimental design was a Randomized Complete Block Design with three replications. The Halisbey (Virginia type) variety was used as a plant material in this research. The planting pattern was used as twin-row and conventional single-row. The row spacing was $70 \mathrm{x}$ $25 \times 70 \mathrm{~cm}, 75 \times 25 \times 75 \mathrm{~cm}$ and $80 \times 25 \times 80 \mathrm{~cm}$ for twin-row planting pattern and $70 \mathrm{~cm}$ for single-row pattern. Intra-row spacing of 10,15 and $20 \mathrm{~cm}$ was arranged for different plants population. According to a two-year average, the highest pods yield $\left(7833.6 \mathrm{~kg} \mathrm{ha}^{-1}\right)$ was obtained from $70 \times 25 \times 70 \times 10 \mathrm{~cm}(21.05$ plants $\mathrm{m}^{-1}$ ) twin-row planting pattern while the yield was $6688.8 \mathrm{~kg} \mathrm{ha}^{-1}$ in single-row planting pattern as $70 \mathrm{x} 15 \mathrm{~cm}$ $\left(9.43\right.$ plants $\left.\mathrm{m}^{-1}\right)$. The yield increase was $17.86 \%$ in $70 \times 25 \times 70 \times 10,16.70 \%$ in $75 \times 25 \times 75 \times 10$ and $15.79 \%$ in $80 \times 25 \times 80 \times 10$ twin-row pattern, compared with traditional single-row planting pattern.
\end{abstract}

Keywords: Main crop, peanut, plant density, pod yield and twin row

\section{INTRODUCTION}

Peanut (Arachis hypogaea L.) is an important oil seed crop and grown throughout the tropics between $40^{\circ}$ South and $40^{\circ}$ North of the equator where annual rainfall varies between $500-1200 \mathrm{~mm}$ and daily temperature average is higher than $20{ }^{\circ} \mathrm{C}$ in the world (Arioglu et al. 2013 and Arioglu, 2014).

Peanut seeds contain high percentage of oil (35-56\%), protein (25-30\%) and carbohydrate (\%21). For these reason, it is an important crop for human nutrition (Gulluoglu et al.2016a). Peanut seeds commonly utilize for vegetable oil production and other products such as snack food and peanut butter (Caliskan et al. 2008). The annual world peanut production was around 45 million tonnes and it is the fifth major oilseeds crop in the world (FAO, 2015).

The number of plant per unit area is one of the important yield determinants of field crops. So that planting density is one of the main factors that have an important role on growth, yield and quality of peanut. It is important to accommodate the most appropriate number of plants per unit area to obtain better yield (Gulluoglu et al.2016b).
The response of peanut to plant density has been investigated in many areas of the world. Investigation of growth and yield performance of peanut with special reference to arrangement has been conducted and the result showed that leaf area index, crop growth rate, pod growth rate, pod and kernel yield have increased by increasing plant density (Kiniry et al., 2005).

Egli (1988) and Wells (1993) reported that, there are two general concepts to describe the relationship between row spacing, plant densities and yield. Firstly, maximum yield can be obtained only if the plant community produces enough leaf area to provide maximum isolation interception during reproductive growth. Secondly, equidistant spacing between plants will maximize yield because it minimizes inter plant competition.

Egli (1988) reported that, the spatial distribution of plants in a crop community is an important determinant of yield and many experiments have been conducted to determine the spacing between rows and within the rows that maximizes yield. Some researchers reported that, maximum yield could be obtained only if the plant community produced enough leaf area to provide maximum light interception during reproductive growth (Shibles et al., 1966; Tanner and Hume, 1978), and 
Pendleton and Hartwing (1973) reported that, equidistant spacing between plants affected interplant competition.

Wright and Bell (1992) suggested that in peanut, by reducing plant density, pod yields were increased and maximum yield was obtained when the plant density was 11-14 plants per $\mathrm{m}^{2}$. Baldwin et al. (1998) reported that a significant increase in yield of $381 \mathrm{~kg} \mathrm{ha}^{-1}$ and total sound mature kernel (TSMK) with the twin-row spacing over the conventional row pattern when averaged across four runner cultivars and locations. Also, McGriff et al. (1999) reported that similar yield and grade increases at peanut. Yilmaz (1999) in a study on the effect of different plant densities of two peanut cultivars found that highest pod yield was obtained at $60 \times 15 \mathrm{~cm}$ spacing. Kaushik and Chaubey (2000) observed that pod yield of peanut was significantly affected by row spacing. The pod yield of 30 $\mathrm{cm}$ inter-row spacing was significantly higher than that of $45 \mathrm{~cm}$ inter row spacing.

Kadiroglu (2012) reported that significantly higher yield in twin row planting compared to single row planting pattern. Several researchers have reported higher yields in close spaced compared to wide spaced groundnut systems (Mickelson and Renner, 1997; Sorensen et al., 2005; Ahmad et al., 2007; Kurt, 2007; Edwards et al., 2008; Godsey and Vaughan, 2009), usually attributed to higher plant population densities that effectively utilize water, nutrients and perhaps more importantly light (Wells et al., 1993). Peanut pod yield was higher in twin row planting patterns than when grown in single row planting patterns.

Peanut is mostly (80\%) grown as a main crop with conventional cropping system in Turkey (Gulluoglu, 2011). Traditionally, peanut planting patterns consist of single rows spaced $70 \mathrm{~cm}$ apart consistently. Current cultivation equipment doesn't permit to further increase plant density in conventional system although previous studies indicated the advantage of high plant density on kernel yield. Some earlier experiments, especially in USA revealed that peanut yield can be increased by twin row planting pattern.

Twin row planting pattern is a new cultivation technique in peanut production in Turkey and very little research has been done to document the effects on yield or grade characteristics. The objective of this study was to determine to impact of twin row planting pattern and plant population on pod yield and yield components of peanut in Cukurova region, Turkey.

\section{MATERIALS AND METHODS}

\section{Materials}

This study was conducted at the Cukurova University research farm as a main crop in 2013 and 2014 in Adana, Turkey (Southern Turkey, 36 $36^{\circ} \mathrm{N}, 35^{\circ} 18^{1}$ E; 23 elevation). Halisbey (Virginia type) peanut variety was used as a plant material in this research.

The texture of the experimental soil was clay loam. The soil tests in both years indicated a $\mathrm{pH}$ of 7.7 with high concentrations of $\mathrm{K}_{2} \mathrm{O}$ and low concentrations of $\mathrm{P}_{2} \mathrm{O}_{5}$. In addition, the organic matter and nitrogen content of the soil was very low. The lime content was $22.3 \%$ in the upper layers with increased levels in lower layers.

Winters are mild and rainy, whereas summers are dry and warm, which is a typical of a Mediterranean climate in Adana (Turkey). The differences between the experimental years and long term for the climatic data were not found very important (Table 1). The average monthly air temperature during the research period (AprilOctober) was 18.1 to $28.6{ }^{\circ} \mathrm{C}$ in 2013 , whereas it was in the 18.3 to $29.1{ }^{\circ} \mathrm{C}$ range in 2014 . The total rainfall was $132.4 \mathrm{~mm}$ and $191.5 \mathrm{~mm}$ during the growing periods in 2013 and 2014, respectively. The average relative humidity was ranged from $47.9 \%$ to $72.3 \%$ in 2013 and $62.9 \%$ to $72.6 \%$ in 2014 .

Table 1. The average monthly temperature, monthly precipitation and relative humidity during the 2013, 2014 and long term (19502015) growing seasons in Adana-Turkey (Anonymous, 2014).

\begin{tabular}{lcccrrrrrr}
\hline \multirow{2}{*}{ Months } & \multicolumn{3}{c}{ Avg. temperature $\left({ }^{\mathbf{O}} \mathbf{C}\right)$} & \multicolumn{3}{c}{ Precipitation (mm) } & \multicolumn{3}{c}{ Relative humidity $(\%)$} \\
& 2013 & 2014 & LT & 2013 & 2014 & \multicolumn{1}{c}{ LT } & 2013 & 2014 & LT \\
\hline April & 18.1 & 18.3 & 17.5 & 43.2 & 18.6 & 54.7 & 72.0 & 69.2 & 67.3 \\
May & 22.7 & 21.3 & 21.7 & 57.4 & 22.4 & 47.6 & 72.3 & 70.4 & 66.9 \\
June & 25.3 & 24.8 & 25.6 & 0.3 & 1.7 & 19.8 & 65.7 & 70.5 & 68.0 \\
July & 28.2 & 28.2 & 28.1 & 0.0 & 0.3 & 7.0 & 65.2 & 72.6 & 71.6 \\
August & 28.6 & 29.1 & 28.5 & 0.0 & 0.3 & 5.3 & 69.0 & 70.3 & 71.0 \\
September & 25.3 & 25.9 & 25.9 & 15.0 & 80.4 & 17.6 & 63.1 & 64.1 & 65.4 \\
October & 19.5 & 21.0 & 21.3 & 16.5 & 67.8 & 40.6 & 47.9 & 62.9 & 61.6 \\
\hline
\end{tabular}

*LT: Long term

The field experiments were laid out in Randomized Complete Block Design with three replications in both years. The experimental sites were cultivated deeply by the moldboard following the harvest of the previous crop in the autumn and then the soil was prepared by using disked-harrowed the day of planting in both years. Before planting, $250 \mathrm{~kg} \mathrm{ha}^{-1}$ of DAP $\left(45 \mathrm{~kg} \mathrm{ha}^{-1} \mathrm{~N}, 115 \mathrm{~kg} \mathrm{ha}^{-1}\right.$
$\mathrm{P}_{2} \mathrm{O}_{5}$ ) fertilizers were applied in both years. Ammonium nitrate $(33 \% \mathrm{~N})$ at the rates of $200 \mathrm{~kg} \mathrm{ha}^{-1}$ was applied two times; before first (beginning of flowering) and second (pod formation) irrigation. The plot size was varied from $14.0 \mathrm{~m}^{2}$ to $21.0 \mathrm{~m}^{2}$ according to planting pattern and row distance. Twin-row and single-row planting pattern were sown in Figure 1. 


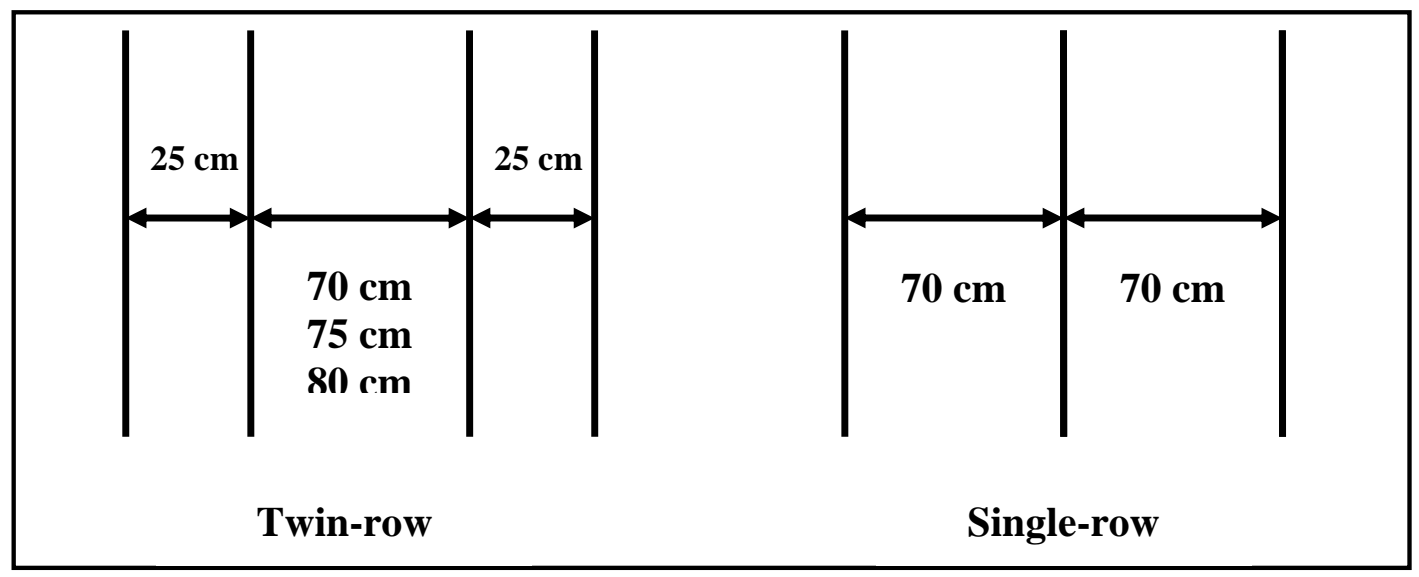

Figure 1. Twin-row and single-row planting patterns

The seeds were planted by hand in the first week of April ( $5^{\text {th }}$ of April) in each year of the study. The twin-row planting pattern was arranged as $70 \times 25 \times 70 \mathrm{~cm}, 75 \times 25 \times 75$ $\mathrm{cm}$ and $80 \times 25 \times 80 \mathrm{~cm}$, and plant spacing was arranged as
$10 \mathrm{~cm}, 15 \mathrm{~cm}$ and $20 \mathrm{~cm}$ (10 different plant populations). The planting patterns and plant population were given in Table 2.

Table 2. The planned planting patterns and plant populations in experiment

\begin{tabular}{|c|c|c|c|c|}
\hline Planting patterns & $\begin{array}{c}\text { Row spacing } \\
\text { (cm) }\end{array}$ & $\begin{array}{c}\text { Plant spacing } \\
(\mathrm{cm})\end{array}$ & $\begin{array}{l}\text { Plant numbers } \\
\left(\text { plant } \mathbf{~ m}^{-2}\right)\end{array}$ & $\begin{array}{l}\text { Seeding rate* } \\
\left(\mathrm{kg} \mathrm{ha}^{1}\right)\end{array}$ \\
\hline Twin-row & $70 \times 25$ & 10 & 21.05 & 252.6 \\
\hline Twin-row & $70 \times 25$ & 15 & 13.90 & 166.8 \\
\hline Twin-row & $70 \times 25$ & 20 & 10.53 & 126.4 \\
\hline Twin-row & $75 \times 25$ & 10 & 20.00 & 240.0 \\
\hline Twin-row & $75 \times 25$ & 15 & 13.30 & 158.4 \\
\hline Twin-row & $75 \times 25$ & 20 & 10.00 & 120.0 \\
\hline Twin-row & $80 \times 25$ & 10 & 19.05 & 228.6 \\
\hline Twin-row & $80 \times 25$ & 15 & 12.57 & 150.8 \\
\hline Twin-row & $80 \times 25$ & 20 & 9.52 & 114.4 \\
\hline Single-row $* *$ & 70 & 15 & 9.43 & 113.2 \\
\hline
\end{tabular}

During the growing period, recommended fungicides (active ingredients are Prochloraze + Tubeconazole and Azoxystrobin) were applied to control insects and diseases. During the growing period, other standard cultural practices were applied at proper time intervals. The plants were harvested by hand when the $60 \%$ of the pods are matured in both growing seasons ( $5^{\text {th }}$ of October).

\section{Methods}

Pod number and pod weight per plant and fancy pod (first quality pod) number percentage was measured from 20 plants randomly selected from each plot at the harvesting time. Yield data per plot was measured in a similar way from all remaining plants excluding the very end on each side of the two central rows for the single row planting and the four central rows for the twin row planting pattern. 100 kernel weight and shelling percentage data were obtained after harvesting (Gulluoglu et al., 2016c).

Determination of oil percentage: Oil was extracted from peanut seeds using (Soxhlet), and oil percentage was estimated according to Association of Official Analytical chemists (AOCS, 1989). Determination of Protein percentage: Nitrogen percentage in seeds was estimated using (Micro-Kjeldahl) method according to Association of Official Analytical chemists (AOCS, 1989). Protein percentage was calculated according to the following equation: Protein percentage $=$ Nitrogen percentage $(\mathrm{N} \%)$ x 6.25)

The data were statistically analysed by using JUMP 8.1.0 statistical software with Randomized Complete Block design. The Least Significant Differences (LSD) test was used to compare the treatments at 0.05 level. 


\section{RESULTS AND DISCUSSIONS}

Pod weight and Pod number per plant
The data regarding to pod weight and pod number per plant at different planting pattern and plant population in main cropped peanut production were shown in Table 3.

Table 3. The effect of plant density and planting pattern on pod weight $\left(\mathrm{g} \mathrm{plant}^{-1}\right)$ and pod number (no. plant $\left.{ }^{-1}\right)$ of per plant in main cropped peanut production in 2013, 2014 and two years average in Adana

\begin{tabular}{|c|c|c|c|c|c|c|c|}
\hline \multirow{2}{*}{$\begin{array}{c}\text { Row spacing } \\
(\mathrm{cm})\end{array}$} & \multirow{2}{*}{$\begin{array}{l}\text { Plant numbers } \\
\left(\text { plant } \mathbf{~ m}^{-2}\right)\end{array}$} & \multicolumn{3}{|c|}{ Pod Weight $\left(\right.$ g plant $\left.^{-1}\right)$} & \multicolumn{3}{|c|}{ Pod Number (no. plant ${ }^{-1}$ ) } \\
\hline & & 2013 & 2014 & Average & 2013 & 2014 & Average \\
\hline $70 \times 25-10^{*}$ & 21.05 & $36.77 \mathrm{~d}$ & $37.80 \mathrm{e}$ & $37.28 \mathrm{f}$ & $16.78 \mathrm{e}$ & $15.71 \mathrm{~g}$ & $16.24 \mathrm{~h}$ \\
\hline $70 \times 25-15^{*}$ & 13.90 & $53.41 \mathrm{c}$ & $54.63 \mathrm{~d}$ & $54.02 \mathrm{e}$ & $23.70 \mathrm{~d}$ & $20.55 \mathrm{e}$ & $22.13 \mathrm{f}$ \\
\hline $70 \times 25-20 *$ & 10.53 & $68.97 \mathrm{a}$ & $62.75 \mathrm{~b}$ & $65.86 \mathrm{c}$ & $30.50 \mathrm{~b}$ & $26.07 \mathrm{c}$ & $28.28 \mathrm{c}$ \\
\hline $75 \times 25-10 *$ & 20.00 & $38.70 \mathrm{~d}$ & $39.32 \mathrm{e}$ & $39.01 \mathrm{f}$ & $17.92 \mathrm{e}$ & $17.30 \mathrm{fg}$ & $17.61 \mathrm{~g}$ \\
\hline $75 \times 25-15^{*}$ & 13.30 & $55.05 \mathrm{bc}$ & $56.98 \mathrm{~cd}$ & $56.01 \mathrm{de}$ & $24.53 \mathrm{~cd}$ & $22.95 \mathrm{~d}$ & $23.74 \mathrm{e}$ \\
\hline $75 \times 25-20 *$ & 10.00 & $69.23 \mathrm{a}$ & $72.61 \mathrm{a}$ & $70.92 \mathrm{~b}$ & $31.69 \mathrm{ab}$ & $28.28 \mathrm{~b}$ & $29.99 \mathrm{~b}$ \\
\hline $80 \times 25-10 *$ & 19.05 & $39.57 \mathrm{~d}$ & $40.29 \mathrm{e}$ & $39.93 \mathrm{f}$ & $18.27 \mathrm{e}$ & 18.75 ef & $18.51 \mathrm{~g}$ \\
\hline $80 \times 25-15^{*}$ & 12.57 & $59.14 \mathrm{~b}$ & $58.95 \mathrm{bc}$ & $59.05 \mathrm{~d}$ & $25.62 \mathrm{c}$ & $24.52 \mathrm{~cd}$ & $25.07 \mathrm{~d}$ \\
\hline $80 \times 25-20 *$ & 9.52 & $72.97 \mathrm{a}$ & $75.84 \mathrm{a}$ & $74.41 \mathrm{a}$ & $32.78 \mathrm{a}$ & $30.53 \mathrm{a}$ & $31.66 \mathrm{a}$ \\
\hline $70 x 15 * *$ & 9.43 & $70.88 \mathrm{a}$ & $72.46 \mathrm{a}$ & $71.67 \mathrm{ab}$ & $31.63 \mathrm{ab}$ & $30.38 \mathrm{a}$ & $31.01 \mathrm{ab}$ \\
\hline $\operatorname{LSD}(5 \%)$ & - & 5.173 & 4.213 & 4.554 & 1.817 & 1.807 & 1.237 \\
\hline
\end{tabular}

${ }^{*}$ Twin-row. ${ }^{* *}$ Single-row

As it can be seen in Table 3, the pod weight plant ${ }^{-1}$ values varied between $36.77-72.97 \mathrm{~g}$ in 2013 , between $37.8-75.84 \mathrm{~g}$ in 2014 and 37.28-74.41g in a two-year average. The differences between the plant densities were statically significant for pod weight per plant in 2013, 2014 and both year averages. The pod weight per plant was increased from $37.28 \mathrm{~g}$ to $74.41 \mathrm{~g}$ when the plant population was decreased from 21.05 plant $\mathrm{m}^{-2}$ to 9.52 plant $\mathrm{m}^{-2}$ in a two-year average in twin-row pattern.

Crop yield is determined by the efficiency with which plant population uses available environmental resources for growth. When the peanut was grown in low plant densities, plants more benefit from water, solar energy and nutrition. For this reason, the pod number and pod weight per plant was increased when the plant population decreased. These results are in agreement with the findings of Sorensen et al. (2005), Kurt (2007), Kadiroglu (2012), Konlan et al. (2013) and Dapaah et al. (2014)

There was a statistically significant difference in pod number per plant among the plant densities in different planting pattern in both years. The pod number per plant values varied between $16.78-32.78$ plant $^{-1}$ in 2013 and between 15.71-30.53 plant $^{-1}$ in 2014 (Table 3). By increasing intra-row spacing at the same row spacing in twin-row planting pattern, the number of pods per plant was significantly increased in both years. The pod number per plant was found higher in 2013 than in 2014.

The number of pods per plant varied between 16.2431.66 plant $^{-1}$ in a two-year average. The pod number per plan was increased when the plant population density decreased. According to a two-year average, the highest number of pods (31.66 plant-1) were recorded for $80 \times 25 \times 80 \times 20 \mathrm{~cm}$ planting pattern while the lowest pod number per plant (16.24 plant-1) were recorded for $70 \times 25 \times 70 \times 10 \mathrm{~cm}$ twin row planting pattern (Table 3 ). The differences between the single-row planting pattern
$(70 \times 15 \mathrm{~cm})$ and $80 \times 25 \times 80 \times 20 \mathrm{~cm}$ twin-row planting pattern was not significant for pod number per plant. Because, the plant numbers in $\mathrm{m}^{2}$ are very close to each other in these planting pattern.

Giayetto et al. (1998) reported that the number of branching per plant was reduced with the increase of plant density. As plant density was decreased in per unit area, pod number per plant was increased. At low plant density, existing plants developed more branches and pegs because of reduced in competition. Donald (1963) reported that as the number of plants per unit area increased competition for growth resources such as nutrients, water and light also increased. Similar results were reported by others researches (Wright and Bell, 1992; Yilmaz, 1999; Kurt, 2007; Ahmad et al., 2007; Kadiroglu, 2012 and Konlan et al., 2013).

\section{Fancy pod number percentage and shelling percentage}

The data belonging to fancy pod and shelling percentage at different planting pattern and plant population in main cropped peanut production were given in Table 4.

It can be seen in Table 4, the differences between the plant densities were statistically significant for fancy pod number percentage in 2013, 2014 and in a two-year average. The percentage of fancy pod number values varied between $72.75-78.94 \%$ in 2013 , between 76.27 $81.47 \%$ in 2014 and between $74.81-79.93 \%$ in a two-year average. According to a two-year average, the highest fancy pod number percentage was obtained when the plant population was 19.05 plants $\mathrm{m}^{-2}(80 \times 25 \times 80 \times 10 \mathrm{~cm}$ planting pattern). By increasing intra-row spacing at the same row spacing in twin-row planting pattern, the percentage of fancy pod number per plant was significantly decreased in both years (Table 4). The pod number per plant was increased when the plant density decreased in the same planting pattern (Table 3). As plant 
density was decreased in per unit area, pod number per plant was increased. At low plant density, existing plants developed more branches and pegs because of reducing competition. Pod formation and pod filling period of peanut affects by plant density. Pod formation and Pod filling period was decreased by increasing plant density. When the planting density decreased, some of the pods do not fully mature and the fancy pod number percentage decreases. These results are in agreement with the findings of Kurt (2007) and Kadiroglu (2012).

Table 4. The effect of plant density and planting pattern on fancy pod number percentage (\%) and shelling percentage (\%) in main cropped peanut production in 2013, 2014 and two years average in Adana

\begin{tabular}{|c|c|c|c|c|c|c|c|}
\hline \multirow{2}{*}{$\begin{array}{l}\text { Row spacing } \\
\text { (cm) }\end{array}$} & \multirow{2}{*}{ Plant numbers (plant $\mathbf{m}^{-2}$ ) } & \multicolumn{3}{|c|}{ Fancy pod number percentage $(\%)$} & \multicolumn{3}{|c|}{ Shelling Percentage (\%) } \\
\hline & & 2013 & 2014 & Average & 2013 & 2014 & Average \\
\hline $70 \times 25-10 *$ & 21.05 & $74.38 \mathrm{bc}$ & $80.59 \mathrm{ab}$ & $77.48 \mathrm{abc}$ & $65.27 \mathrm{abc}$ & $66.62 \mathrm{ab}$ & $65.95 \mathrm{bc}$ \\
\hline $70 \times 25-15 *$ & 13.90 & $73.68 \mathrm{bc}$ & $78.27 \mathrm{bc}$ & $75.98 \mathrm{bcd}$ & $64.03 \mathrm{~cd}$ & $66.13 \mathrm{ab}$ & $65.08 \mathrm{bcd}$ \\
\hline $70 \times 25-20 *$ & 10.53 & $72.75 \mathrm{c}$ & $76.86 \mathrm{c}$ & $74.81 \mathrm{~d}$ & $63.95 \mathrm{~cd}$ & $65.61 \mathrm{~b}$ & $64.78 \mathrm{~cd}$ \\
\hline $75 \times 25-10 *$ & 20.00 & $75.07 \mathrm{abc}$ & $81.47 \mathrm{a}$ & $78.27 \mathrm{ab}$ & $65.50 \mathrm{abc}$ & $65.94 \mathrm{ab}$ & $65.72 \mathrm{bc}$ \\
\hline $75 \times 25-15 *$ & 13.30 & $74.47 \mathrm{bc}$ & $80.25 \mathrm{ab}$ & $77.36 \mathrm{abcd}$ & $64.03 \mathrm{~cd}$ & $66.70 \mathrm{ab}$ & $65.37 \mathrm{bcd}$ \\
\hline $75 \times 25-20 *$ & 10.00 & $73.11 \mathrm{c}$ & $77.31 \mathrm{abc}$ & $76.21 \mathrm{bcd}$ & $62.54 \mathrm{~d}$ & $65.99 \mathrm{ab}$ & $64.27 \mathrm{~d}$ \\
\hline $80 \times 25-10 *$ & 19.05 & $78.94 \mathrm{a}$ & $80.93 \mathrm{ab}$ & $79.93 \mathrm{a}$ & $66.86 \mathrm{a}$ & $67.81 \mathrm{a}$ & $67.34 \mathrm{a}$ \\
\hline $80 \times 25-15 *$ & 12.57 & $77.86 \mathrm{ab}$ & $80.01 \mathrm{ab}$ & $78.94 \mathrm{a}$ & $65.83 \mathrm{ab}$ & $66.50 \mathrm{ab}$ & $66.17 \mathrm{ab}$ \\
\hline $80 \times 25-20 *$ & 9.52 & $73.51 \mathrm{bc}$ & $79.06 \mathrm{abc}$ & $76.29 \mathrm{bcd}$ & $64.86 \mathrm{bc}$ & $64.84 \mathrm{~b}$ & $64.85 \mathrm{~cd}$ \\
\hline $70 x 15 * *$ & 9.43 & $74.92 \mathrm{abc}$ & $76.27 \mathrm{c}$ & $75.60 \mathrm{~cd}$ & $64.57 \mathrm{bc}$ & $64.95 \mathrm{~b}$ & $64.76 \mathrm{~cd}$ \\
\hline $\operatorname{LSD}(5 \%)$ & - & 4.379 & 3.119 & 2.595 & 1.641 & 1.966 & 1.236 \\
\hline
\end{tabular}

${ }^{*}$ Twin-row. ${ }^{* *}$ Single-row

There was a statistically significant difference in shelling percentage among the plant densities in different planting pattern in 2013, 2014 and in a two-year average. The shelling percentage values varied between 62.54 $66.86 \%$ in 2013 and between $64.84-67.81 \%$ in 2014 (Table 4). The shelling percentage varied between 64.27 $67.34 \%$ in a two-year average. According to a two-year average, the highest shelling percentage (67.34\%) was obtained from $80 \times 25 \times 80 \times 10 \mathrm{~cm}$ planting pattern while the lowest shelling percentage $(64.27 \%)$ was from $75 \times 25 \times 75 \times 20 \mathrm{~cm}$ twin row planting pattern (Table 4). The shelling percentage was decreased when the intra row spacing was increased at the same planting pattern. The fancy pod number percentage was decreased when the intra- row spacing was increased. For this reason, the shelling percentage was decreased. Similar results were reported by Boluk, 1969; Kurt, 2007; Rasekh et al. 2010 and Kadiroglu, 2012.

\section{Protein and oil content}

The data belonging to protein and oil content at different planting pattern and plant population in main cropped peanut production were given in Table 5.

Table 5. The effect of plant density and planting pattern on protein and oil content (\%) in main cropped peanut production in 2013 , 2014 and two years average in Adana

\begin{tabular}{|c|c|c|c|c|c|c|c|}
\hline \multirow{2}{*}{ Row spacing (cm) } & \multirow{2}{*}{ Plant numbers (plant $\mathbf{m}^{-2}$ ) } & \multicolumn{3}{|c|}{ Protein Content $(\%)$} & \multicolumn{3}{|c|}{ Oil Content $(\%)$} \\
\hline & & 2013 & 2014 & Average & 2013 & 2014 & Average \\
\hline $70 \times 25-10^{*}$ & 21.05 & $26.63 \mathrm{~d}$ & $27.66 \mathrm{c}$ & 27.14 cde & $49.31 \mathrm{a}$ & 49.02 & $49.17 \mathrm{ab}$ \\
\hline $70 \times 25-15^{*}$ & 13.90 & $27.19 \mathrm{abc}$ & $28.55 \mathrm{~b}$ & $27.87 \mathrm{~b}$ & $49.35 \mathrm{a}$ & 48.71 & $49.03 \mathrm{ab}$ \\
\hline $70 \times 25-20 *$ & 10.53 & $27.62 \mathrm{a}$ & $29.50 \mathrm{a}$ & $28.56 \mathrm{a}$ & $48.87 \mathrm{ab}$ & 48.14 & $48.51 b c$ \\
\hline $75 \times 25-10^{*}$ & 20.00 & $26.73 \mathrm{~cd}$ & $26.11 \mathrm{fg}$ & $26.42 \mathrm{fg}$ & $49.72 \mathrm{a}$ & 49.18 & $49.45 \mathrm{ab}$ \\
\hline $75 \times 25-15^{*}$ & 13.30 & $26.91 \mathrm{bcd}$ & 26.57 ef & 26.74 ef & $49.05 \mathrm{ab}$ & 48.70 & $48.87 \mathrm{ab}$ \\
\hline $75 \times 25-20 *$ & 10.00 & $27.34 \mathrm{ab}$ & $26.86 \mathrm{de}$ & $27.10 \mathrm{de}$ & $48.69 \mathrm{ab}$ & 48.01 & $48.35 b c$ \\
\hline $80 \times 25-10 *$ & 19.05 & $26.97 \mathrm{bcd}$ & $25.06 \mathrm{~h}$ & $26.02 \mathrm{~g}$ & $50.88 \mathrm{a}$ & 49.20 & $50.04 \mathrm{a}$ \\
\hline $80 \times 25-15^{*}$ & 12.57 & $27.26 \mathrm{ab}$ & $25.43 \mathrm{gh}$ & $26.35 \mathrm{fg}$ & $49.93 \mathrm{a}$ & 48.34 & $49.13 \mathrm{ab}$ \\
\hline $80 \times 25-20 *$ & 9.52 & $27.51 \mathrm{a}$ & $27.58 \mathrm{~cd}$ & $27.54 \mathrm{bc}$ & $46.96 \mathrm{~b}$ & 48.15 & $47.56 \mathrm{c}$ \\
\hline $70 \times 15 * *$ & 9.43 & $26.92 \mathrm{bcd}$ & $27.98 \mathrm{bc}$ & $27.45 \mathrm{bcd}$ & $49.39 \mathrm{a}$ & 49.45 & $49.42 \mathrm{ab}$ \\
\hline $\operatorname{LSD}(5 \%)$ & - & 0.523 & 0.751 & 0.442 & 2.217 & NS & 1.311 \\
\hline
\end{tabular}

The protein content values varied between $26.63 \%$ and $27.62 \%$ in 2013 , between $25.06 \%$ and $29.50 \%$ in 2014 and between $26.02 \%$ and $28.56 \%$ in a two-year average. The statistically significant differences were found between the plant densities for protein content in both years and in a tow-year average. The highest protein content $(27.62 \%$ and $29.50 \%$ ) was obtained from $70 \times 25 \times 70 \times 20 \mathrm{~cm}$ planting pattern in both years (Table 5). The protein content was increased when the planting density decreased at the same planting pattern. Salem et al. (1985) also reported that plant density and planting pattern effect on protein content, in contrast Arioglu and Arioglu (2007), Kurt (2007), Kadiroglu (2012). 
There was a statistically significant difference between the plant densities in different planting pattern for oil content value in 2013 and in a two-year average, whereas there was no statistically significant difference in 2014. Oil content varied between $46.96-50.88 \%$ in 2013, between $48.01-49.45 \%$ in 2014 and between 47.56$50.04 \%$ in a two-year average. By increasing intra-row spacing at the same row spacing in twin-row planting pattern, the oil content was decreased in both years (Table 5). According to a two-year average, the highest oil content $(50.04 \%)$ was obtained from $80 \times 25 \times 80 \times 10 \mathrm{~cm}$ planting pattern. Kurt (2007) also reported that plant density and planting pattern are not affected on oil content, contrary to Kadiroglu (2012).

\section{Hundred (100) kernel weight and pod yield}

Pod yield per hectare and 100 kernel weights data at different planting pattern and plant population density are shown in Table 6

Table 6. The effect of plant density and planting pattern on pod yield per hectare $\left(\mathrm{kg} \mathrm{ha}^{-1}\right)$ in main cropped peanut production in 2013, 2014 and two years average in Adana

\begin{tabular}{|c|c|c|c|c|c|c|c|}
\hline \multirow{2}{*}{ Row spacing (cm) } & \multirow{2}{*}{ Plant numbers (plant $\mathbf{m}^{-2}$ ) } & \multicolumn{3}{|c|}{100 kernel weight $(\mathrm{g})$} & \multicolumn{3}{|c|}{ Pod yield $\left(\mathrm{kg} \mathrm{ha}^{-1}\right)$} \\
\hline & & 2013 & 2014 & Average & 2013 & 2014 & Average \\
\hline $70 \times 25-10 *$ & 21.05 & 132.46 & $136.36 \mathrm{~b}$ & 134.41 & $7791,0 \mathrm{a}$ & $7976.2 \mathrm{a}$ & $7883,6 \mathrm{a}$ \\
\hline $70 \times 25-15 *$ & 13.90 & 133.24 & $137.40 \mathrm{ab}$ & 135.32 & $7466.9 \mathrm{ab}$ & $7726.9 \mathrm{ab}$ & $7596.9 \mathrm{a}$ \\
\hline $70 \times 25-20 *$ & 10.53 & 134.33 & $139.58 \mathrm{ab}$ & 136.96 & $7241.7 \mathrm{ab}$ & $7524.1 \mathrm{ab}$ & $7382.9 \mathrm{ab}$ \\
\hline $75 \times 25-10 *$ & 20.00 & 133.85 & $137.16 \mathrm{ab}$ & 135.50 & $7742.0 \mathrm{a}$ & $7869.3 \mathrm{ab}$ & $7805.7 \mathrm{a}$ \\
\hline $75 \times 25-15^{*}$ & 13.30 & 134.89 & $138.76 \mathrm{ab}$ & 136.83 & $7304.7 \mathrm{ab}$ & $7519.9 \mathrm{ab}$ & $7412.3 \mathrm{ab}$ \\
\hline $75 \times 25-20 *$ & 10.00 & 134.94 & $139.57 \mathrm{ab}$ & 137.26 & $6925.3 \mathrm{bc}$ & $7261.7 \mathrm{ab}$ & $7093.5 \mathrm{ab}$ \\
\hline $80 \times 25-10 *$ & 19.05 & 134.73 & $139.08 \mathrm{ab}$ & 136.91 & $7517.7 \mathrm{a}$ & $7972.4 \mathrm{a}$ & $7745.0 \mathrm{a}$ \\
\hline $80 \times 25-15 *$ & 12.57 & 135.26 & $140.83 \mathrm{ab}$ & 138.05 & $7271.2 \mathrm{ab}$ & $7368.8 \mathrm{ab}$ & $7320.0 \mathrm{ab}$ \\
\hline $80 \times 25-20 *$ & 9.52 & 133.17 & $141.39 \mathrm{a}$ & 137.28 & $6931.7 \mathrm{bc}$ & $7205.5 \mathrm{ab}$ & $7068.6 \mathrm{ab}$ \\
\hline $70 \times 15 * *$ & 9.43 & 135.08 & $140.17 \mathrm{ab}$ & 137.63 & $6666.1 \mathrm{c}$ & $6711.6 \mathrm{~b}$ & $6688.8 \mathrm{~b}$ \\
\hline $\operatorname{LSD}(5 \%)$ & - & N.S & 4.835 & NS & 557.58 & 1160.88 & 879.07 \\
\hline
\end{tabular}

There was a statistically significant difference between the plant densities in different planting pattern for 100 kernel weight value in 2014 , whereas there was no statistically significant difference in 2013 and in a twoyear average. The kernel weight value was ranged between 132.46-135.26 $\mathrm{g}$ in 2013, between 136.36-141.39 $\mathrm{g}$ in 2014 and 134.41-138.05 $\mathrm{g}$ in a two-year average. According to a two-year average, the highest kernel weight $(138.05 \mathrm{~g})$ was obtained from $80 \times 25 \times 80 \times 15 \mathrm{~cm}$ twin row planting pattern, while the lowest pod yield $(134.41 \mathrm{~g})$ was obtained $70 \times 25 \times 70 \times 10 \mathrm{~cm}$ twin row planting pattern. The 100 kernel weight was decreased when the plant density increased in the same row spacing at the twin row planting pattern. Similar results were reported by Kurt (2007) and Kadiroglu (2012).

It can be seen in Table 6 , the pod yield ha $^{-1}$ values varied between $6666.1-7791.0 \mathrm{~kg} \mathrm{ha}^{-1}$ in 2013 and between $6711.6-7976.2 \mathrm{~kg} \mathrm{ha}^{-1}$ in 2014. Statistically significant differences were observed for pod yield ( $\mathrm{kg} \mathrm{ha}$ ${ }^{1}$ ) among the plant densities at different planting pattern. The highest pod yield $\left(7791.0 \mathrm{~kg} \mathrm{ha}^{-1}\right.$ and $\left.7976.2 \mathrm{~kg} \mathrm{ha}^{-1}\right)$ was recorded for $70 \times 25 \times 70 \times 10 \mathrm{~cm}$ twin-row planting pattern, while lowest pod yield $\left(6666.1 \mathrm{~kg} \mathrm{ha}^{-1}\right.$ and 6711.6 $\mathrm{kg} \mathrm{ha}^{-1}$ ) was recorded for $70 \times 15 \mathrm{~cm}$ single row planting pattern in 2013 and 2014, respectively. The pod yield of peanut in 2014 was generally higher than in 2013. Peanut pod yield was higher in twin row planting patterns than when grown in single row planting pattern in both years. Twin row and single row planting pattern compared, the yield increase was found $16.9 \%$ in 2013 and $18.8 \%$ in 2014.
Pod yield however, was not directly related to yield components in both years. Generally, decrease in spacing reduced the number of pods plant ${ }^{-1}$ and pod weight plant $^{-1}$ but the additional plants per $\mathrm{m}^{-2}$ in higher densities compensated this reduction and resulting in higher pod yield. Such compensation effects have been reported by Ahmad et al. (2007) and Norden and Lipscomb (1974). Thus spacing arrangement that resulted in high plant population density was more efficient in the use of solar energy and other resources for pod production (Virk et al. 2005)

According to a two-year average, the pod yield varied between $6688.8 \mathrm{~kg} \mathrm{ha}^{-1}$ and $7883.6 \mathrm{~kg} \mathrm{ha}^{-1}$. Among different plant population densities, significant variation was observed at $(\mathrm{p}<0.5)$ with highest pod yield $(7883.6 \mathrm{~kg}$ $\mathrm{ha}^{-1}$ ) recorded for $70 \times 25 \times 70 \times 10 \mathrm{~cm}$ twin row planting pattern, while the lowest pod yield $(6688.8 \mathrm{~kg}$ ha-1) recorded for 70x15 single row planting pattern (Table 6). These results showed that pod yield was higher in standard twin row planting pattern than when grown in single row planting pattern. Peanut grown in twin-row planting pattern has yielded about $17.9 \%$ more than the conventional planting pattern.

Pod yield was increased when the plant density increased in the same row distance at twin row planting pattern (Table 6). Peanut pod yield per hectare was higher in standard twin row planting patterns than when grown in conventional single row planting patterns. Lanier et al. (2004) compared single-row and standard twin-row planting patterns in Virginia type peanut varieties, and they found that peanut yield was higher in standard twin 
row planting patterns than single-row planting patterns. Our findings were also confirmed their results.

Peanut yield increases with increasing of number of plants per unit area. Twin-row planting pattern provide us to increase plant density up to more than double in the field while it is almost impossible in conventional singlerow planting pattern. Earlier reports have shown that yield increases in these stems are closely related to more efficient utilization of solar energy and other growth resources in narrow spaced peanut crop which translated into higher pod yield (Virk et al. 2005).

Lanier et al. (2004) reported that, pod yield increased when peanut was seeded in standard twin row planting patterns compared with seeding in the single row planting pattern. Ahmed et al. (2007) and Konlan et al., (2013) had earlier reported that pod yield was $16.0 \%$ higher in narrow-row plantings than traditional wide-row crop. Kadiroglu (2012) found out that pod yield was $22 \%$ higher in twin-row plantings when compared with traditional single-row groundnuts. Similar findings have been reported by earlier studies (Norden and Lipscomb, 1974; Mozingo, 1984; Giayetto et al., 1998; Sorensen et al., 2004; Sorensen et al., 2005; Lanier et al., 2004; Virk et al., 2005; Kurt, 2007; Balkcom et al., 2010 and Rasekh et al., 2010)

\section{CONCLUSION}

Planting density is one of the main factors that have an important role on growth, yield and quality of peanut. It is important to accommodate the most appropriate number of plants per unit area of land to obtain better yield. Establishment of optimum population per unit area of the field is essential to get maximum yield.

Twin row planting pattern is new technology in peanut production in Turkey and very limited research has been done to document the effects on yield or grade characteristics. Traditionally, peanut planting patterns have been single rows consistently spaced $70 \mathrm{~cm}$ apart. It seems impossible rising plant density per unit area with conventional crop mechanized system. Peanut yield increases with increasing of number of plants per unit area. But twin-row planting pattern could provide that increasing. In USA and other developed countries, the yield of peanut increased by increasing the number of plants per unit area through twin row cropping pattern. Pod yield however, was not directly related to yield components in both years. Generally, decrease in spacing reduced the number of pods plant ${ }^{-1}$ and pod weight of per plant, but the additional plants $\mathrm{m}^{-2}$ more than compensated for the reduction, resulting in higher pod yield. Results clearly indicated that higher pod yield can be obtained by using twin-row planting pattern than conventional single row planting pattern in Cukurova region. Based on these results; suitable planting pattern could be suggested as twin-row planting and high plant density main crop peanut planting in Cukurova region of Turkey.

\section{LITERATURE CITED}

Anonymous, 2014. The Meteorological Data for Adana.The Turkish State Meteorological Service Adana Regional Directorship, 2013, 2014 and long term.

Ahmad, A., M. Rahim and U, Khan. 2007. Evaluation of different varieties, seed rates and row spacing of groundnut, planted under agro-ecological conditions of Malakand division. Journal of Agronomy, 6(2):385-387

AOCS. 1989. Official and recommended methods. American oil Chemists' Society Press. Champaingn, IL, USA

Arioglu, E. and H, Arioglu. 2007. Ana ürün yerfistığ 1 yetiştiriciliğinde bitki yoğunluğunun verim ve bazı tarımsal özelliklere etkisi. Türkiye VII. Tarla Bitkileri Kongresi, Erzurum (Turkish).

Arioglu H., Kurt, C., Bakal, H., Onat, B., Gulluoglu, L. and Sinan, N.S. 2013. The Effects of Pix (Mepiquat-Chloride) Application in Different Growing Stages on Pod Yield and Some Agronomic Characters of Peanut. Turkish Journal of Field Crops. 18(2):260-267

Arioglu, H.H. 2014. The oil seed crops growing and breeding. The Publication of University of Cukurova, Faculty of Agriculture, No:A-70, 204 p. Adana-Turkey

Baldwin, J.A., J.P. Beasley, S.L. Brown, J.W. Todd and A.K. Culbreath. 1998. Yield, grade, and tomato spotted wilt incidences of four peanut cultivars in response to twin row versus single row planting patterns. Proc. Am. Peanut Res. Educ. Soc. 31: 54

Balkcom, K.S., F.J. Arriaga, K.B. Balcom, and S.L. Boykin., 2010. Single and twin-row peanut production within narrow and wide strip tillage systems. Agronomy Journal, 102(2):507-512

Boluk, A. 1969. Yerfıstığı çeşit verim denemesi. Batı Akdeniz Tarımsal Arş. Ens. Yıllık Çalışma Raporu, 10s, Antalya (Turkish)

Caliskan, S., M.E. Caliskan, and Arslan, M. 2008. Genotypic differences for reproductive growth, yield, and yield components in groundnut (Arachis hypogaea L.). Turk. J. Agr. Forest., 32, 415-424.

Dapaah, H.K, I. Mohammed, and R.T. Awuah, 2014. Growth yield performance of groundnuts (Arachis hypogaea L.) in response to plant density. International Journal of Plant and Soil Science 3(9):1069-1082, 2014

Donald, C.M. 1963. Competition among crops and pasture plants. Advances in Agronomy, 15: 17-27

Edwards, R. P., Kemmerait, R. C. and Beasley, J. P. 2008. Evaluation of top five planted peanut varieties in Irwin county Georgia.

Egli, D.B. 1988. Plant density and soybean yield. Crop Science, 28:977-980

FAO. 2015. Crop Production Statistics. Food and Agriculture Organization of the United Nations, Rome, Italy (http://www.fao.org/crop/ statistics)

Giayetto,O., G.A. Cerioni and W.E. Asnal. 1998. Effect of sowing spacing on vegetative growth, dry matter production and peanut pod yield. Peanut Science, 25: 86-92

Godsey, C.B., and W. Vaughan. 2009. Twin-row and single row comparisons. $\quad$ http://oilseeds.okstate.edu/productioninformation/peanut/Twin-row\%20vs\%20Single-row.pdf. (Accessed November 12, 2016)

Gulluoglu, L. 2011. Effects of Growth Regulator Applications on Pod Yield and Some Agronomic Characters of Peanut in Mediterranean Region. Turkish Journal of Field Crops. $\underline{16(2)}: 210-214$ 
Gulluoglu, L., H. Bakal, B. Onat, A. El Sabagh, and H. Arioglu. 2016a. Characterization of peanut (Arachis hypogaea L.) seed oil and fatty acids composition under different growing season under Mediterranean environment. Journal of Experimental Biology and Agricultural Sciences. DOI:http://dx.doi.org/10.18006/2016, 4(5S):564-571

Gulluoglu, L., H. Bakal, H. Arioglu. 2016b. The Effects of Twin-row Planting Pattern and plant Population on Seed Yield and Yield Components of Soybean at Late DoubleCropped Planting in Cukurova Region. Turkish Journal of Field Crops. 21(1):59-65

Gulluoglu, L., H. Bakal, B. Onat, C. Kurt, and H. Arioglu. 2016c. The Effect of Harvesting Dates on Yield and Some Agronomic and Quality Characteristics of Peanut Grown in Mediterranean Region (Turkey) Turkish Journal of Field Crops. 21(2): 224-232 (DOI:10.17557/tifc.20186)

Kadiroglu, A., 2012. Yerfistığı (Arachis hypogaea L.) yetiştiriciliğinde farklı çeşitler ve sıra üzeri mesafelere göre tek ve çift sıralı ekim yöntemlerinin karşılaştırılması. Suleyman Demirel University, Institute of Science. PhD Thesis (Turkish).

Kaushik, M.K. and A.K. Chaubey. 2000. Response of rainy season bunch groundnut (Arachis hypogaea L.) to row spacing and seed rate. Field Crops Research, 20: 407-410

Kiniry, J.R., Simpson, C.E., Schubert, A.M. and Reed, J.D. 2005. Peanut leaf area index, light interception, radiation use efficiency, and harvest index at three sites in Texas. Field Crop Research 91:297-306

Konlan, S., J. Sarkodie-addo, E. Asare and M.J. Kombiok. 2013. Groundnut (Arachis hypogaea L.) varietal response to spacing in the Guinea Savanna agro-ecological zone of Ghana: growth and yield. African J. Of Agriculture Research, 8(22): 2769-2777

Kurt, C., 2007. Ana ürün yerfistığ yetiştiriciliğinde tek ve çift sıralı ekim yöntemlerinin verim ve önemli tarımsal özelliklere etkisi. Cukurova University, Institute of Science. MSc Thesis (Turkish).

Lanier, J.E., D.L. Jordan, J.F. Spears, R. Wells, P.D. Johnson, J.S. Barnes, C.A. Hurt, R.L. Brandenburg and J.E. Bailey. 2004. Peanut response to planting, row spacing, and irrigation. Agronomy Journal, 96: 1066-1072

McGriff, D.E., J.A. Baldwin and J.E. Hudgins. 1999. Yield response of several peanut cultivars when planted in single and twin row patterns during 1997-98 in Decatur county. Proc. Am. Peanut Res. Educ. Soc. 31:54

Mickelson J.A. and K.A. Renner. 1997. Weed control using reduced rates of post-emergence herbicides in narrow and wide row soybean. J. Prod. Agric. 10:431-437
Mozingo, R.W. 1984. Skip-row planting and row pattern effects on Virginia-type peanut cultivars. Agronomy journal, 76:660-662

Pendleton, J.W. and E.E. Hartwing. 1973. Crop production and management. In B.E. Caldwell (ed.) Soybean Improvement, production and uses. 16: 211-237

Rasekh, H., J. Asghari, M.N. Safarzadeh Wishkai, S.L. Massoumi and R. Zakerinejad. 2010. Effect of planting pattern and plant density on physiological characteristics and yield of peanut (Arachis hypogaea L.) in Iran. Research J. Of Biological Sciences, 5(8):542-547

Sorensen, R., D. Sternitzke and M. Lamb. 2005. Row orientation and seeding rate on yield, grade, and disease incidence of peanut with subsurface drip irrigation. Peanut Science, 28, $15-18$.

Norden, A.J. and R.W. Lipscomb. 1974. Influence of plant grown habit on peanut production in narrow rows. Crop Sci. 14: $454-457$

Salem, M. S., M. Serry and M.M. Soliman. 1985. Plant densityyield relation in peanuts. Field Crops, 38(6), 17-21.

Shibles, R.M., C.R. Weber and D.E. Byth. 1966. Effect of plant population and row spacing on soybean development and production. Agronomy journal, 58:99-102

Sorensen, R.B., L.E. Sconyers, M.C. Lamb and D.A. Sternitzke. 2004. Row orientation and seeding rate on yield, grade, and stem rot incidence of peanut with subsurface drip irrigation. Peanut Science, 31: 54-58

Tanner, J.W. and D.J. Hume. 1978. Management and production. In: A.G. Norman (Ed.) Soybean Physiology Agronomy and Utilization. Academic Press, New York. Pp.157-217

Virk, A.S., L.N. Kaul, B.S. Bhangoo and A. Sing. 2005. Influence of planting techniques and plant population on biology and pod productivity of summer groundnut varieties. Res. Crops. 6(1): 173-174.

Wells, R.J., J.W. Burton and T.C. Kilen. 1993. Soybean growth and light interception: response to differing leaf and stem morphology. Crop Science, 33:520-524

Wright, G.C. and M.J. Bell. 1992. Plant population studies on peanut (Arachis hypogaea L.) in subtropical Australia. 3. Growth and Water Use During a Thermal Drought Stress. Aust J. Exp. Agriculture, 32: 197-203

Yilmaz, H.A. 1999. Effect of different plant densities of two groundnut (Arachis hypogaea L.) genotypes on yield, yield components, oil and protein contents. Turkish j. of Agriculture and Forestry, 23: 299-308 